\title{
ЕНЦИКЛОПЕДИЧНА ХРОНІКА
}

\author{
Олег Савченко, Оксана Давиденко \\ Інститут енциклопедичних досліджень НАН Украӥни, \\ Київ, Украӥна
}

\section{Шевченківська енциклопедія}

18 лютого 2016 року в Національному музеї Тараса Шевченка презентували «Шевченківську енциклопедію в 6-ти томах (2012-2015). Захід відбувся за участі голови редакційної колегії, директора Інституту літератури імені Т. Г. Шевченка НАН України Миколи Жулинського, колективу науково-видавничого проекту, а також відомих науковців і письменників, зокрема Павла Гриценка, Івана Дзюби, Івана Драча, Дмитра Павличка, Михайла Сидоржевського, Ганни Скрипник, Дмитра Стуса, Олександра Федорука, Ярослава Яцкова.

«Ми залучали широке коло авторів не лише Інституту літератури, а й працівників Національного музею Тараса Шевченка, Інституту мистецтвознавства, фольклористики та етнології імені М. Т. Рильського, Інституту української мови, Інституту історії України, бо мали на меті зробити цілісний комплекс з біографічних відомостей, осмислити його літературну, образотворчу, епістолярну спадщину. Дослідити Шевченка в усій багатоманітності його вияву, як особистісного так і творчого», - зазначив під час виступу академік Микола Жулинський.

«Шевченківська енциклопедія» репрезентує світові постать творця нації, геніального українського поета й видатного художника, окреслює його роль у становленні національної культури, у боротьбі за державну незалежність України. Видання пропонує надійну фактографічну й інтерпретаційну базу для вивчення і популяризації спадщини Шевченка.

Над виданням шевченкознавці працювали понад двадцять років. Особливо інтенсивно робота розгорнулася в останнє десятиріччя перед 200-літнім ювілеєм від дня народження поета. «Шевченківська енциклопедія» містить 6307 статей різного обсягу - від короткої довідки до розлогого монографічного нарису, 5800 ілюстрацій, із яких 453 - на кольорових вклейках. Загальний обсяг видання становить 5360 сторінок (646 обліково-видавничих аркушів). 


\section{Шаховий енциклопедичний словник}

На початку 2016 року світ побачив другий том «Шахового енциклопедичного словника» обсягом майже 800 сторінок, автором-упорядником якого $\epsilon$ волинянин Володимир Батура - шкільний учитель української мови й літератури з міста Горохів. В одному з інтерв'ю він зазначив, що до створення цієї праці намагався долучити провідних шахістів України, функціонерів із обласних шахових федерацій, проте ніхто ідею не підтримав, тому робота з підготовки видання велася самостійно й розгорнулася на десятиліття.

Енциклопедичний словник містить різноманітні аспекти шахової тематики - від прізвищ і коротких біографій шахових майстрів усього світу до цікавих комбінацій на найрізноманітніших турнірах різних часів. Видання подає авторські екскурси у вітчизняну історію шахів, розповідає про історичні особливості шахової сфери в усіх областях України, Криму та найбільших містах нашої держави.

Це перше українське енциклопедично-довідкове видання із шахової тематики. Загалом енциклопедій чи енциклопедичних словників про спорт в Україні обмаль; прикметною особливістю $€$ те, що їх в основному створюють ентузіасти-аматори енциклопедичної справи. Наприклад, у 2010 і 2012 роках з’явилися два енциклопедичні довідники про футбол Левка Легкого, відомого футбольного літописця, які є першими вітчизняними спеціалізованими енциклопедичними джерелами з тематики про футбол.

\section{Енциклопедія художнього металу}

10 березня 2016 року в Науковій бібліотеці Львівського національного університету імені Івана Франка відбулася презентація двох томів «Енциклопедії художнього металу», яку уклав професор Львівської національної академії мистецтв Ростислав Шмагало й опублікував 2015 року. Перший том енциклопедії описує ремесла й галузі виробництва художнього металу, його морфологічну класифікацію, технології виготовлення виробів, термінологічні покажчики металів, коштовних каменів, прикрас, посуду, художнього металу в архітектурі, зброярства, релігійного вжитку, медальєрства тощо. У територіальному й художньому вимірах охоплено історичний матеріал та стилістичні періоди предметно-видового розвитку художнього металу від давніх цивілізацій Євразії, Середньовіччя до початку XXI ст. в Україні і світі. Другий том подає типологічні ланки, мистецтвознавчі експертні оцінки галузей ковальства, ювелірства, художніх лиття, емалі та зброярства України XX - початку XXI ст.

Декоративно-ужиткове мистецтво $є$ найдавнішим видом і способом художньої діяльності людини, його існуванням окреслюють розвиток давніх цивілізацій, відкривають загадки історії, міфології, культури. Тому автор поставив собі за мету створенням цієї праці сприяти утвердженню української ідентичності в її історичному та сучасному вимірах через мистецтвознавчий аналіз археологічних пам'яток художнього металу, ковальства та 
лиття в архітектурі, виробів релігійного вжитку, медальєрства, фалеристики, атрибутів влади та державності тощо.

\section{Українська нафтогазова енциклопедія}

12 травня 2016 року в приміщенні Будинку вчених у Львові презентували «Українську нафтогазову енциклопедію» - працю, творцями якої є провідні вітчизняні фахівці цієї галузі під керівництвом професора Володимира Іванишина. На презентації керівник проекту розповів, що Україна має значний потенціал у системі підземних сховищ газу. «Основна мета цього видання - щоб наші спеціалісти, які працюють в геології, газовій і нафтовій промисловості, мали свою енциклопедію про розвиток української й зарубіжної промисловості», - наголосив В. Іванишин.

Загалом це перша енциклопедія з нафтогазової сфери. У ній подано термінологію нафтогазової галузі, історію i розвитку в промислових регіонах України; представлено підземні сховища газу в Україні, вітчизняну нафтопереробну та нафтохімічну промисловості, а також окреслено нафтогазові провінції та басейни світу. До цього українська енциклопедистика у відповідній галузі мала лише спеціалізований «Енциклопедичний словник морських нафтогазових технологій» (2003), а також тематично розгалуженіший енциклопедичний проект «Гірнича енциклопедія у 6-ти книгах (1998-2013).

\section{Енциклопедія мистецтва Полтавщини}

13 травня 2016 року у виставковому залі музею Національної академії образотворчого мистецтва і архітектури в Києві відбулася презентація двотомної «Енциклопедії мистецтва Полтавщини» Віталія Ханка. Відомий в Україні мистецтвознавець, заслужений працівник культури України, член Міжнародної асоціації критиків мистецтва, активіст Полтавського обласного товариства «Просвіта» імені Тараса Шевченка В. Ханко збирав матеріали для цієї енциклопедіі понад 40 років. Це - фундаментальна художня енциклопедія регіонального типу, яка узагальнює досягнення мистецтвознавчої думки Полтавського краю від найдавніших часів до початку XXI ст. У двотомнику подано статті про художників і народних майстрів, меценатів та фундаторів храмів, населені пункти краю - центри розвитку мистецтва, мистецькі навчальні заклади, музеї і художні колекції, промислові артілі й фабрики художніх виробів. Представлено понад 500 портретів. Серед них окрема частина - діаспора, якій автор присвятив великий розділ. Він виявив понад сім десятків відомих людей зарубіжжя, чиї корені пов'язані з Полтавщиною, а саме: С. Делоне і Г. Старицька з Франції, М. де Гранмезон з Канади, М. Бутович, М. Дмитренко, С. Литвиненко, П. Рожанківський і Є. Шуматова зі США, Е. МанеКац з Ізраїлю, М. Малецький з Хорватії, І. Майковський з Болгарії, Р. Пельше з Латвї. Загальна кількість статей - 1848.

До цього з-під пера В. Ханка вийшли також інші регіональні довідкові видання, зокрема «Словник мистців Полтавщини», «Миргородський мистецький словник». 


\section{Полтавіка}

14 червня 2016 року в Полтавському краєзнавчому музеї імені Василя Кричевського у Полтаві відбулася презентація 9-го тому видання «Полтавіка. Полтавська Енциклопедія», присвяченому образотворчому й декоративному мистецтву (у 2-х книгах). Започаткований науково-видавничий проект «Полтавіка» - це універсальна енциклопедія з найрізноманітніших галузей науки, техніки, культури Полтавського краю, систематизує знання про найважливіші надбання Полтавщини від найдавніших часів до сьогодення, узагальнює найістотніші і різнопланові відомості про регіон.

Автором ідеї та керівником проекту є Олександр Білоусько - директор Центру дослідження історії Полтавщини, член Національної спілки краєзнавців України, заслужений учитель України, лауреат Полтавської обласної премії імені І. Котляревського в номінації «Освіта» та премії імені Д. Яворницького Національної спілки краєзнавців України.

У дев’ ятому томі під назвою «Образотворче і декоративне мистецтво» висвітлено найважливіші віхи мистецького процесу на Полтавщині від найдавніших часів до початку XXI століття, продемонстровано полтавськість як невід’ємну частину художньої культури людства. У тематичних статтях описано питання живопису, скульптури, графіки, декоративного і фотомистецтва. Низку статей присвячено питанням, які в радянській науці свідомо фальшували чи замовчували. У роботі над томом взяли участь провідні центри мистецтвознавства Полтавської області - Полтавський художній музей, Полтавський краєзнавчий музей, а також відомі вчені, представники наукових і творчих колективів, колекціонери.

\section{Українська мала енциклопедія}

Українська енциклопедистика має чимало золотих сторінок. Серед значних енциклопедичних надбань нашої країни - «Українська мала енциклопедія» професора Євгена Онацького, яку він уклав в Аргентині впродовж 19571967 років, перебуваючи там в еміграції. Упорядкована зусиллями однієї людини, вона є дещо більшим, аніж просто довідковим виданням - це пам'ятка відданості ідеї, результат багаторічних пошуків та осмислення найдрібніших деталей, які разом утворюють українську ідентичність.

8 вересня 2016 року в Центрі української культури та мистецтва відбулася презентація першого тому нової чотиритомної редакції цього видання. Його підготувало видавництво «Пульсари» за сприяння доктора історичних наук Сергія Білоконя. Презентація зібрала багатьох представників наукової спільноти й інтелігенції, серед яких директор Інституту літератури НАН України Микола Жулинський та директор науково-видавничого центру «Наша культура й наука» Микола Тимошик.

У передмові до перевидання С. Білокінь зазначив: "“Українська мала енциклопедія" Євгена Онацького підсумувала розвиток етнології "Розстріляного відродження". Мало того, що автор дає поклики на "Історію 
України-Руси" та "Історію української літератури" Михайла Грушевського (наукову спадщину нашого найбільшого історика у шістнадцяти книжках УМЕ прискіпливо розписано), текст рясніє посиланнями на "Наукові збірники” Української академії наук за роки 1924-1929 (інакше кажучи, всі річники, що вийшли), збірники “Первісного громадянства" (1926-1930, яке в рамках Академії готувала Катерина Грушевська, “Історію українського письменства" Сергія Єфремова, праці Володимира Гнатюка, Зенона Кузелі, Євгена Кагарова, Валерії Козловської, Костя Копержинського, Петра Курінного, Володимира Січинського, Вадима й Данила Щербаківських та інших. Як соборник Онацький широко використовував матеріали "Народних пісень Галицької та Угорської Русі" Якова Головацького, "Гуцульщини" В. Шухевича, “Записок” Наукового товариства імені Шевченка і так далі й таке інше».

«Це була справа його життя. Все, що у своїй душі виплекав, він намагався передати своєму народу. Це вияв справжнього патріотизму. Є. Онацький намагався зібрати якомога глибший матеріал для осмислення на покоління вперед. Усе, аби плекати національну гідність та позбуватися комплексу меншовартості. Презентуючи цю працю, ми фактично повертаємо Євгена Онацького в український культурний дискурс», - зазначила Лариса Копань, директор видавництва «Пульсари».

\section{Львівський державний університет фізичної культури. 1946-2016}

15 вересня 2016 року у Львівському державному університеті фізичної культури відбулася презентація енциклопедії «Львівський державний університет фізичної культури. 1946-2016» 3 нагоди 70-річчя навчального закладу. На презентації керівник редакційно-видавничого відділу Оксана Борис докладно розповіла про енциклопедію, їі зміст, особливості створення. Загальний обсяг видання становить 488 сторінок, на яких подано 47 статей про структурні підрозділи університету, близько 500 статей-персоналій та 800 світлин.

\section{Франківська енциклопедія}

31 січня 2017 року в Інституті Івана Франка НАН України (колишне Львівське відділення Інституту літератури імені Т. Г. Шевченка) в межах засідання наукового семінару «Перехресні стежки» відбулася презентація першого тому видання «Франківська енциклопедія» (у 7-ми томах). Це - персональна енциклопедія, присвячена I. Франкові, знаковій для України особистості, письменнику, публіцисту, мислителю, громадському й політичному діячеві. Її складають статті про письменників, літературознавців, фольклористів, мовознавців - тих, хто потрапив у поле зору I. Франка. Статті енциклопедії висвітлюють прижиттєві зв'язки I. Франка з ними, його відгуки та роздуми про попередників і сучасників, а також спогади, дослідження та висловлювання про письменника. Фактично «Франківська енциклопедія» $€$ 
другою українською після «Шевченківської енциклопедії» персональною літературною енциклопедією. Без сумніву, це фундаментальне видання є вагомим внеском у літературознавство й енциклопедичну справу України і світу та здобутком академічної науки ${ }^{1}$.

Перший том (літери А-Ж) має назву «Іван Франко і нова українська література: попередники та сучасники», його опубліковано 2016 року з нагоди 160 років від дня народження та 100 років від дня смерті Каменяра. Керівники енциклопедичного проекту - Микола Жулинський, Євген Нахлік.

\section{Українська музична енциклопедія}

14 березня 2017 року в Музеї видатних діячів української культури Лесі Українки, Миколи Лисенка, Панаса Саксаганського, Михайла Старицького відбулася презентація 4-го тому «Української музичної енциклопедії (літери Н-O), яку від 2006 року готує Інститут мистецтвознавства, фольклористики та етнологї імені М. Т. Рильського НАН України (заплановано 6 томів). Захід пройшов спільно з Київським інститутом музики імені Р. М. Ілієра в рамках щорічного фестивалю мистецтв «Шевченківський березень» масштабної мистецької акції найстарішого професійного навчального закладу України, який у 2018 році святкує своє 150-річчя. На презентацї виступили завідувач Музею Роксана Скорульська, викладач-методист Інституту музики Ольга Непосєдова, науковці Інституту мистецтвознавства, фольклористики та етнологї імені М. Т. Рильського НАН України Ольга Кушнірук та Оксана Летичевська.

\section{Велика українська енциклопедія}

28 березня 2017 року у Великому конференц-залі Національної академії наук України ДНУ «Енциклопедичне видавництво» презентувала перший том Великої української енциклопедії (літери А-Акц). У вступному слові доктор історичних наук Олена Любовець зазначила, що перший том цієї енциклопедії став результатом спільної роботи їхнього колективу зі структурними підрозділами Національної академії наук України та викладачами вишів. У заході взяли участь і виступили з вітальними словами багато відомих науковців - головний редактор видання академік НАН України Вадим Локтєв, віце-президент НАН України Анатолій Загородній, академік НАН України Іван Дзюба, академік НАН України Валерій Смолій, директор Інституту української мови НАН України Павло Гриценко, головний науковий співробітник Інституту історї України НАН України Станіслав Кульчицький, завідувач відділу еволюційно-генетичних основ систематики Інституту зоології імені I. Шмальгаузена НАН України Сергій Межжерін.

${ }^{1}$ В інтерв’ю з президентом НАН України академіком Б. Є. Патоном наголошено, що «Франківська енциклопедія належить до найбільших досягнень літературознавчої науки у 2016 році (див.: Вісник НАН України. 2017. № 1. С. 5). 
«Велика українська енциклопедія» (ВУЕ) - багатотомне енциклопедичне видання універсального характеру, що готується відповідно до Указів Президента України № 1/2013 «Про Велику українську енциклопедію» та № 7/2015 «Питання підготовки та видання Великої української енциклопедії». Основна мета «Великої української енциклопедії» - систематизувати і сприяти поширенню об'єктивних знань про розвиток людської цивілізації та внесок України у світову історію й культуру. В анотації до першого тому зазначено: «ВУЕ у стислій та доступній формі представляє найвидатніші події та постаті світової історії, науки, культури; інтерпретує найважливіші відкриття людського розуму і витвори людських рук, суспільні інституції та господарські структури, що вплинули на долю народів; відображає рух політичних і культурних ідей та динаміку наукових уявлень. Україна постає не лише органічною складовою частиною багатоманітного світу, а й суб’єктом його інтерпретацї̈. За попередніми даними, обсяг енциклопедії має скласти 70-100 тисяч статей у 30-ти томах. Матеріали енциклопедії доступні також у мультимедійній версії в мережі Інтернет ${ }^{2}$.

\section{Київська духовна академія в іменах: 1819-1924}

18 травня 2017 року авторський колектив презентував результати чотирирічного наукового дослідження - енциклопедію «Київська духовна академія в іменах: 1819-1924». Презентацію розпочав Почесний президент Національного університету «Києво-Могилянська академія», відповідальний редактор видання, голова редколегії та член авторського колективу В’ячеслав Брюховецький: «Я щасливий, що долучився до цієї роботи, бо це дозволило створити одну з найкращих, на мій погляд, енциклопедій в Україні». Далі він зазначив, що ця енциклопедія, підготовлена на підставі вивчення широкого кола джерел, передусім новознайдених архівних документів і матеріалів, не лише відтворює історію Київської духовної академї, а й є вагомим кроком у вивченні історї освіти та науки на теренах Східної Европи.

Упорядник і науковий редактор енциклопедіі Марина Ткачук представила авторський колектив і всіх тих, хто опікувався виданням двотомника, розповіла про його підготовку, задум і зміст, а також вказала на основні здобутки й результати здійсненого наукового дослідження. «Енциклопедіі зазвичай узагальнюють наявне знання, натомість наша енциклопедія містить нове знання », - зауважила пані Марина, наголошуючи на численних наукових відкриттях, зроблених у процесі виконання цього енциклопедичного проекту, результати якого суттєво примножують та уточнюють сучасні уявлення про життя і творчість викладачів, очільників і вихованців Київської духовної академіі XIX - початку XX ст., а також увиразнюють їхній вагомий внесок у розвиток української освіти, науки, культури.

\footnotetext{
${ }^{2}$ Режим доступу: http://db.vue.gov.ua
} 


\section{Енциклопедія Сучасної України}

9 червня 2017 року за сприяння краєзнавчого відділу «Одесика» Одеської національної наукової бібліотеки Інститут енциклопедичних досліджень НАН України презентував 16-й і 17-й томи «Енциклопедії Сучасної України» в рамках XVIII Всеукраїнської виставки «Українська книга на Одещині». У приміщенні Одеської обласної універсальної бібліотеки імені Михайла Грушевського захід зібрав зацікавлених в енциклопедичній справі одеситів, більшість із яких - автори статей до ЕСУ (Костянтин Васильєв, Тетяна Казначеєва, Світлана Крижевська, Валерій Левченко, Світлана Мірошниченко, Інна Рікун, Любов Федченко та Юрій Ющенко). Співробітники Інституту О. Іщенко та О. Савченко, презентуючи нові томи, розповіли присутнім про «Енциклопедію Сучасної України», iї особливості, окреслили ії значення для українського суспільства і світу, визначальні риси, за якими видання відрізняється від інших енциклопедій, поінформували про електронну версію томів ЕСУํ․ Окрему увагу було звернуто на плідні зв'язки ЕСУ з Одеським краєм, зокрема на значний внесок одеських авторів у підготовку томів ЕСУ; порушено питання регіональної енциклопедистики Одеського краю.

У жовтні 2017 року вийшов друком 18-й том «Енциклопедії Сучасної України» (літери «Лт»- «Малицький»). Матеріали тому вже доступні також на сайті електронної ЕСУ. Нині редакція енциклопедії працює над 19-м i 20-м томами.

\section{Енциклопедія освіти Хмельниччини}

5 жовтня 2017 року на засіданні Великої методичної ради Управління освіти, молоді та спорту Красилівської районної державної адміністрації Хмельницької області з нагоди відзначення 50-річчя створення районних методичних кабінетів в Україні було презентовано «Енциклопедію освіти Хмельниччини». Видання комплексно висвітлює різні аспекти становлення та функціонування системи освіти від початку XX століття до сьогодення в регіоні. Подає цілісну картину розвитку освітньої галузі краю в інституціях, напрямках діяльності та персоналіях, відображає сучасні погляди на історичні події та постаті, містить аналіз досягнень, проблем і перспектив освітніх процесів у Хмельницькій області. В енциклопедії узагальнено та об’єктивно відображено систематизовану інформацію за такими напрямами: історія педагогіки та освіти області, дошкільна освіта, загальна середня освіта, професійно-технічна освіта, вища освіта, післядипломна освіта, неформальна освіта, корекційна освіта та деякі інші.

«Енциклопедія освіти Хмельниччини» є втіленням прагнення педагогічної громадськості регіону вшанувати працю своїх попередників та сучасників. Ідея видання знайшла схвальні відгуки у громадських і наукових колах Хмельниччини та була підтримана Хмельницькою обласною радою й Хмельницькою обласною державною адміністрацією. Енциклопедію підготували фахівці

\footnotetext{
${ }^{3}$ Режим доступу: http://esu.com.ua
} 
Хмельницького обласного інституту післядипломної педагогічної освіти, Кам'янець-Подільського національного університету, Хмельницького національного університету та Хмельницького університету управління і права. 3 електронною копією видання можна ознайомитися на сайті Хмельницького обласного інституту післядипломної педагогічної освіти.

\section{Енциклопедія Національної опери України}

До свого ювілейного 150-го театрального сезону Національний академічний театр опери та балету України імені Тараса Шевченка у Києві підготував для своїх шанувальників багато яскравих вистав, прем'єр, концертних програм, тематичних виставок та окремих видавничих проектів, серед яких - енциклопедія «Національна опера України».

7 листопада 2017 року відбулася презентація першого тому цього видання (на літери А-К). «Нині Національна опера перебуває у зеніті свого розквіту, є флагманом музично-театрального мистецтва в Україні і належить до найкращих театрів Європи і світу. За останні 30-40 років не було таких високих показників заповнення залу і, відповідно, прибутків, як зараз. Ніколи театр не мав такої широкої гастрольної діяльності, як в останні роки», - заявив на презентації генеральний директор театру Петро Чуприна. Він наголосив, що випуск енциклопедії, яку присвячено всім, хто причетний до театру, починаючи з його заснування, є важливою подією для всієї країни. Енциклопедія подає довідкову інформацію про корифеїв та сучасних представників оперних і балетних труп, художньо-постановочної частин. Загалом перший том вміщує понад 4000 статей. За словами П. Чупринки, подібного характеру енциклопедій у світі обмаль, причому зовсім не всі найвідоміші театри мають такі видання; проведено велику наукову та дослідницьку роботу, до якої було залучено багато музикознавців.

\section{Енциклопедія НТШ}

15 листопада 2017 року Наукове товариство імені Шевченка (НТШ) за підтримки департаменту внутрішньої та інформаційної політики Львівської обласної державної адміністрації презентувало 3-й том енциклопедії «Наукове товариство імені Шевченка» - перше багатотомне видання про найдавніше наукове громадське товариство в Україні. Ця енциклопедія є спільним видавничим проектом НТШ та Інституту енциклопедичних досліджень НАН України. Вона є важливим культурно-просвітницьким проектом, який привертає увагу широких кіл громадськості до історичних засад розвитку освіти й науки в Україні. Це «книга знань», яка репрезентує цілісний і багатовимірний образ інституції: мету і завдання, структуру, основні видання, персоналіі, а також установи, що працювали при НТШ упродовж 1873-2016 років. Окремо в енциклопедії фігурують крайові НТШ і їхні осередки, які діють в Україні та за кордоном. Енциклопедія охоплює історію всіх сфер життя інституції та ї контакти з різними національними, закордонними науковими інституціями та навчальними закладами. За своїм змістом пропоноване видання є істот- 
ним доповненням наукових знань про Україну. У третьому томі подано 305 гасел та 1409 ілюстрацій і 10 картосхем.

Про ексклюзивний характер цього енциклопедичного видання, роботу над наступними томами (заплановано понад 12 томів) розповів голова НТШ Роман Кушнір. На презентації виступили автори статей до енциклопедіі: Роман Пляцко, Юрій Ковалів, Андрій Фелонюк, Степан Гелей та Іван Сварник, а також голова Західного наукового центру НАН України і МОН України Зіновій Назарчук і Дарія Гонтарева - донька вже покійного дійсного члена НТШ, відомого літературознавця, бібліографа та етнографа Мирослава Мороза, саме він розпочинав реалізацію цього проекту у 80-х роках минулого століття. У презентації взяли участь представники низки бібліотек Львова та Львівської області, до фондів яких було передано презентоване видання.

\section{Вікіпедія}

28 листопада 2017 року, як зазначено на сайті громадської організації «Вікімедія Україна» ${ }^{4}$, у «Вікіпедії» було опубліковано 750-тисячну статтю українською мовою. Отже, нині енциклопедичний ресурс містить три чверті мільйона статей українською. Українськомовний розділ «Вікіпедії» - найбільший енциклопедично-довідкове електронне джерело українською мовою; посідає 16-те місце за кількістю статей серед усіх мовних розділів «Вікіпедії». У 2016 році сторінки української «Вікіпедії» переглянули понад 500 мільйонів разів. За лічильником статей на головній сторінці «Вікіпедії» їі редактори слідкують постійно і тепер готуються до наступного круглого числа - 800 тисяч. За теперішньої швидкості створення статей (в середньому 280 статей на добу) цю кількість буде досягнуто орієнтовно у травні 2018 року.

\section{Енциклопедія про країни світу}

Наприкінці 2017 року вийшов друком перший том енциклопедії «Країни світу і Україна», яку підготував Інститут всесвітньої історії НАН України з нагоди його 25-річчя та 100-річчя НАН України. Роботу над укладанням цього видання було розпочато в 2015 році, за мету поставлено грунтовний і систематизований виклад історії й опис сучасного етапу розвитку всіх країн світу і їхніх двосторонніх відносин з Україною. Перший том присвячено країнам Північної, Західної і Південної Європи. Видання є компендіумом виважених академічних знань із широкого спектру питань про держави світу, особливості їхнього розвитку та функціонування; особливість видання розлогість статей, що дозволяє в науково виваженому вигляді представити кожну країну.

Як зазначено в передмові, спеціалізовані енциклопедї про країни світу є у Великій Британії, Росіі, Франції тощо. В Україні до цього часу подібна енциклопедія була відсутня, тому «Країни світу і Україна» є першим вітчизняним фундаментальним енциклопедичним виданням такого характеру.

\footnotetext{
${ }^{4}$ Режим доступу: http://wikimediaukraine.wordpress.com
} 


\section{Українська мінералопедія}

У 2017 році в мережі Інтернет запрацювала «Українська мінералопедія» («Українська мінералогічна енциклопедія»). Це академічна онлайн-енциклопедія у галузі мінералогії, яку створено працівниками Інституту геохімії, мінералогії та рудоутворення імені М. П. Семененка НАН України (за редакції академіка НАН України О. М. Пономаренка). Енциклопедичний проект реалізовано з метою надати широкому колу читачів (геологам, географам, колекціонерам мінералів) наукову інформацію про розповсюдження мінералів на території України, їхні фізичні властивості, особливості хімічного складу, умови утворення, практичне значення. Сайт енциклопедії подає також новини з мінералогії та пропонує дискусію щодо способу подальшого утворення українських синонімів латинописних назв мінеральних видів, затверджених Міжнародною мінералогічною асоціацією.

\section{ENCYCLOPEDIC NEWSREEL}

Oleh Savchenko, Oksana Davydenko NASU Institute of Encyclopedic Resarch, Kyiv, Ukraine 